\title{
Description of the female of the orb-weaver spider Testudinaria gravatai (Araneae: Araneidae)
}

\author{
Renato Augusto Teixeira \& Arno Antonio Lise
}

\author{
Laboratório de Aracnologia, Museu de Ciências e Tecnologia, Pontifícia Universidade Católica do Rio Grande do Sul. \\ Avenida Ipiranga 6681, Prédio 40, sala 167, $90619-900$ Porto Alegre, Rio Grande do Sul, Brasil. \\ E-mail: renatoaug.tx@gmail.com; lisearno@pucrs.br
}

\begin{abstract}
Testudinaria Taczanowski, 1879 includes nine valid species; only four of these species have both sexes described. In this paper we describe the female of $T$. gravatai Levi, 2005, which can be recognized specially by the abdominal pattern of spots. Testudinaria gravatai Levi, 2005 is similar to T. quadripunctata Taczanowski, 1879, but can be distinguished from that species by the presence of a single median excavation on the upper margin of the epigynal atrium; by copulatory duct almost straight in the basal portion and narrower in the distal portion. We have based our description on a single available female, collected in Criciúma, Santa Catarina, Brazil, a new locality record for the species.
\end{abstract}

KEY WORDS. Neotropical region; new record; taxonomy.

Testudinaria (type-species T. geometrica Taczanowski, 1879) was recently revised by Levi (2005), who considered the genus a senior synonym of Arcidius Simon, 1893. Some years before, Levi (2002) synonymyzed Nanduti Mello-Leitão, 1945 with Testudinaria.

According with TACZANOWSKI (1879), Testudinaria includes small species with heart-shaped abdomen; abdomen generally flat with regular sclerotized polygons; eyes subequal, arranged in three groups, the medians and the laterals on tubercles. LEvI (2005) added the following characters to the diagnosis provided by Taczanowski: the less of the radix on the male palpus and the presence of macrosetae on the legs of some species.

Currently, Testudinaria includes nine valid species, from which only five have both males and females described: $T$. bonaldoi Levi, 2005, T. geometrica Taczanowski, 1879, T. quadripunctata Taczanowski, 1879, T. rosea (Mello-Leitão, 1945) and T. unipunctata (Simon, 1893). Testudinaria debsmithi Levi, 2005, T. elegans Taczanowski, 1879 and T. lemniscata (Simon, 1893) are known only from female specimens and T. gravatai Levi, 2005, only from the male. In this paper, we describe the female of T. gravatai from Criciúma, Santa Catarina, Brazil, which we identified based on the general coloration and the dorsal abdominal color pattern. Even though our specimen was collected from a locality from which the species has not been previously recorded and, in spite of the lack of male specimens in our sampling to confirm identification, we decided to consider it a member of $T$. gravatai until more evidence is gathered, thus avoiding the proposal of a possibly invalid new name.

\section{MATERIAL AND METHODS}

The specimen examined is deposited in the collection of Myriapoda and Arachnida of the Museu de Ciências e Tecnologia da Pontifícia Universidade Católica do Rio Grande do Sul (MCTP, A.A. Lise). The format of the description follows LeVI (2005). The measurements are in millimeters and the abbreviations are those traditionally used in Araneology.

\section{TAXONOMY}

\section{Testudinaria gravatai Levi, 2005}

Figs $1-5$

Testudinaria gravatai Levi, 2005: 193, figs 39-41 (male holotype from Morungava, Gravataí, Rio Grande do Sul, Brazil, 11.I.1959, Ditadi leg., deposited in MCN 11460/not examined). Platnick, 2010.

Diagnosis. The female of $T$. gravatai is similar to the female of T. quadripunctata, but differs by the presence of a single median excavation on the upper margin of the epigynal atrium, by the basal portion of the copulatory duct being almost straight and by the distal portion being thinner. The copulatory ducts and spermathecae are similar to those of other species of the genus, as T. quadripunctata, T. unipunctata and T. bonaldoi. Both males and females can be easily distinguished by the typical abdominal dorsal color pattern (Fig. 3; Levi 2005: fig. 39).

Description. Carapace, sternum, legs and abdomen yellow-white as in the male (Fig. 1). Lateral eyes blackened. Femora I and II with a black longitudinal stripe on retromargin. Femur 

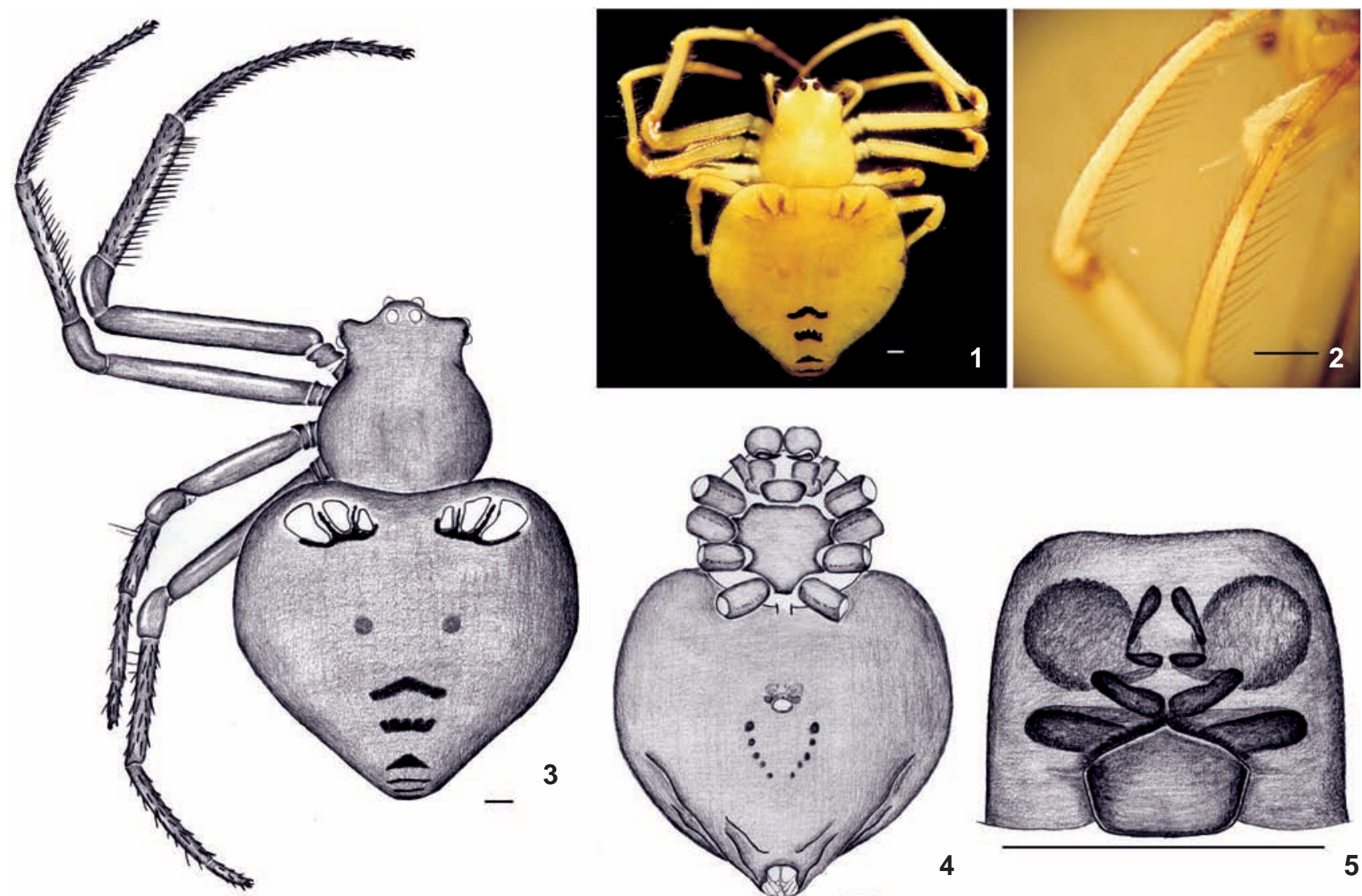

Figures 1-5. Testudinaria gravatai, female: $(1,3)$ dorsal view; (2) rows of setae in the $\overline{m e t a t a r s u s ~ I ~ a n d ~ I I ; ~(4) ~ e p i g y n u m, ~ v e n t r a l ~ v i e w . ~ S c a l e ~}$ bar: $0.25 \mathrm{~mm}$.

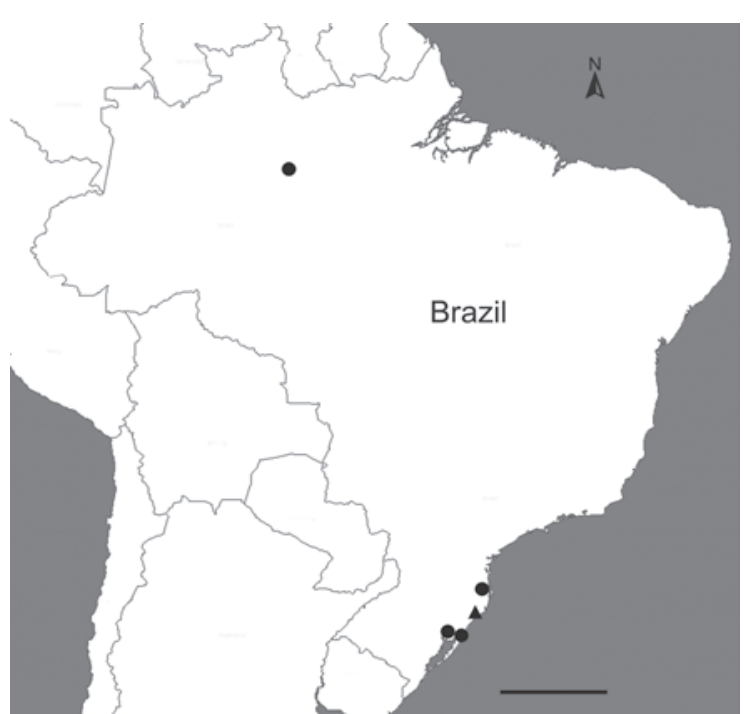

Figure 6. Distribution of T. gravatai. ( $)$ Literature records, $(\mathbf{A})$ new record. Scale bar: $1.000 \mathrm{~km}$.
III with a blackened stripe on the apical retromargin. Tibia II with similar stripe on the ventral face. Remaining legs with small black spot on the ventral apex of tibiae and patellae. Abdomen with a pair of dorsal sigilla darker than the rest of the body; anterior region with tree black rectangles each side internally bordered with milk white and more externally by small black dots. Posteriorly, there are five black horizontal spots; and ventrally there are two parallel rows of small slightly darker sigilla (Figs 1 and 3).Eyes subequals: AME 0.9, PME 0.8, ALE 0.9 and PLE 0.8. AME 1.1 diameter apart from each other and 2.4 diameters from ALE; PME 0.9 diameter apart from each other and 3.3 diameters from PLE. Median eyes area trapezoid, slightly wider than long, slightly narrower behind. Height of clypeus 0.2 approximately 2.0 diameters of AME. Sternum as in the male, 0.6 long, 0.4 wide. Carapace 1.2 long, 1.1 wide, 0.5 height. Abdomen 2.3 long, 2.2 wide, 0.6 high. Relative length of legs: I-II-IV-III. Measurements: I - femur 1.52/ tibia+patella 1.58 /metatarsus $1.16 /$ tarsus $0.46 /$ total 4.75 ; II 1.36/1.38/1.14/0.44/4.34; III - 0.96/0.88/0.66/0.30/2.80; IV $1.30 / 1.30 / 0.96 / 0.32 / 3.88$. Metatarsus I and II with two rows of 
setae in all extension of ventral portion (Fig. 2).Epigynum, on ventral view, presents an atrium that olds more than one third of the total area of the epigynum which has the inferior base almost straight and the upper margin with a median excavation. The copulatory ducts are coiled with proximal portion almost straight and distal one thin and vertical. Spermathecae spherical, situated between the second and third coil of the copulatory duct (Fig. 5).

Material examined. BRASIL, Santa Catarina: Criciúma (Sociedade Recreativa Mampituba, 28³8'33"S, 49¹9'54"W), female, 2.X.2008, F.M. Bianchi leg., МСTP 8823.

Distribution. Brazil, Amazonas, Rio Grande do Sul and Santa Catarina (Fig. 6).

\section{ACKNOWLEDGMENT}

This study was supported by Coordenadoria de Aperfeiçoamento de Pessoal do Ensino Superior (CAPES).

\section{LITERATURE CITED}

LEvi, H.W. 2002. Keys to the genera of araneid orbweavers (Araneae, Araneidae) of the Americas. Journal of Arachnology 30 (3): 527-562.

LeVI, H.W. 2005. The spider genera Heterognatha, Testudinaria and Ursa in South America (Araneae: Araneoidea). Bulletin of the British Arachnological Society 13 (6): 185-198.

Mello-Leitão, C.F. 1945. Arañas de Misiones, Corrientes y Entre Ríos. Revista del Museo de La Plata (N.S., Zool.) 4: 213-302.

Platnick, 2010. The World Spider Catalog. Nova York, American Museum of Natural History, version 10.5. Available at: http:/ /research.amnh.org/iz/spiders/catalog [Accessed: 21/II/2010]

Simon, E. 1893. Descriptions d'espèces et de genres nouveaux de l'ordre des Araneae. Annales de la Société Entomologique de France 62: 299-330.

Taczanowski, L. 1879. Les aranéides du Pérou central. Horae Societatis Entomologicae Rossicae 15: 102-136.

Submitted: 08.VI.2009; Accepted: 27.I.2010.

Editorial responsibility: Antonio D. Brescovit 